\title{
A formal mammalian biostratigraphy for the Late Pleistocene of Britain
}

\author{
Andrew Currant*, Roger Jacobi \\ Department of Palaeontology, Natural History Museum, Cromwell Road, London SW7 5BD, UK
}

\begin{abstract}
A series of distinctive mammalian assemblages spanning much of the British Late Pleistocene is defined on the basis of type localities and a formal biozonation proposed. The Joint Mitnor Cave mammal assemblage-zone includes the famous "Hippopotamus fauna" of the early part of the Last Interglacial complex (Oxygen Isotope Substage 5e). This is succeeded by the Bacon Hole mammal assemblage-zone in which hippopotamus is no longer present and species like mammoth, roe deer and northern vole re-enter the British region. This assemblage-zone appears to represent the later substages of OIS 5. A faunal grouping dominated by bison and reindeer is named the Banwell Bone Cave mammal assemblage-zone and is believed to correlate closely with the Early Devensian (OIS 4). The Pin Hole mammal assemblage-zone includes the familiar mammoth-steppe faunas of the Middle Devensian (OIS 3) dominated by horse, woolly rhinoceros and mammoth. The Lateglacial Interstadial is characterized by the Gough's Cave mammal assemblage-zone in which horse, red deer and humans are well represented (part of OIS 2). No definitive evidence for human activity can be found for a period spanning the Last Interglacial complex (OIS 5) and the Early Devensian (OIS 4). Human populations return to Britain with the Pin Hole mammal assemblage-zone fauna during the Middle Devensian (OIS 3) and reappear after the Dimlington Stadial during the Late Devensian (OIS 2) but in a different faunal association. (C) 2001 Published by Elsevier Science Ltd.
\end{abstract}

\section{Introduction}

Mammalian fossils are conspicuous, common and widespread in many Late Pleistocene deposits in the island of Great Britain. In this paper, we consider the mammalian record for this period and propose a formal biostratigraphy based on repeated patterns of faunal associations, stratigraphic superposition and absolute dating evidence. Our work has involved site investigations, a very thorough re-examination of museum collections around the country and critical appraisal of the extensive literature relating to Late Pleistocene mammal finds within this region. We believe that the biozonation put forward here will have widespread utility and will serve to formalize and extend a provisional framework proposed in an earlier paper (Currant and Jacobi, 1997). We have made one significant change to the original proposal which we believe strengthens this scheme, the substitution of Pin Hole, Creswell Crags, Derbyshire as the type locality for

\footnotetext{
*Corresponding author. Tel.: +44-20-7942-5649; fax: + 44-20-79425546.

E-mail address: a.currant@nhm.ac.uk (A. Currant).
}

our Middle Devensian (OIS 3) assemblage in place of Coygan Cave, Laugharne, Dyfed, which has been destroyed by quarrying. Two new mammal assemblage-zones which were not considered in our previous treatment are added to the formal model, summarized below with approximate OIS correlations in order to locate the coverage of this zonation.

Gough's Cave mammal assemblageLate OIS 2 zone Dimlington Stadial interzone

Pin Hole mammal assemblage-zone Banwell Bone Cave mammal assemEarly OIS 2 OIS 3 OIS 4 blage-zone

Bacon Hole mammal assemblage- Late OIS 5 zone

Joint Mitnor Cave mammal assem- Early OIS 5 blage-zone

We have tried, as far as possible, to use the well established principles of biostratigraphy as they are more generally applied to the rest of the fossiliferous geological succession, but the highly fragmented nature of the Quaternary terrestrial record stretches some of 
the nicer points of standard practice to their practical limits. The actual sequences represented are often of very short duration, making evidence for the direct stratigraphic relationship between some of our proposed assemblage-zones quite hard to establish. The links we have used are sometimes based on inferences derived from lithostratigraphy and absolute dating, and although the purist may not approve of this methodology, no progress in this difficult field would be possible without some degree of pragmatic compromise. We feel that it is more important to the user that this model is robust and useable rather than appearing to be intellectually elegant in its construction. At the end of the day, we believe that we have come up with a testable biostratigraphic model. Indeed, we have tested it ourselves at site after site and on collection after collection. Absolute dating programmes have been instigated specifically to check parts of this framework and so far it has held together very well. We believe very strongly that the type locality concept is essential to this kind of terrestrial sequence biostratigraphy, particularly with such a fragmented record, and it is hoped that the type localities selected here will be used as the basis for future improvements in the resolution of this model. The discussion begins with the oldest unit in our proposed scheme.

\section{The Joint Mitnor Cave mammal assemblage-zone}

A vertebrate assemblage in which hippopotamus is the most distinctive element has long been attributed to the Last Interglacial period (King, 1955; Sutcliffe, 1959)

Table 1

The mammal fauna from Joint Mitnor Cave, Buckfastleigh, Devon

\begin{tabular}{ll}
\hline Sorex araneus Linnaeus, 1758 & Eurasian common shrew \\
Lepus timidus Linnaeus, 1758 & Mountain hare \\
Clethrionomys glareolus (Schreber, 1780) & Bank vole \\
Arvicola terrestris cantiana (Hinton, 1910) & Water vole \\
Microtus agrestis (Linnaeus, 1761) & Field vole \\
Apodemus sylvaticus (Linnaeus, 1758) & Wood mouse \\
Canis lupus Linnaeus, 1758 & Wolf \\
Vulpes vulpes Linnaeus, 1758 & Red fox \\
Ursus arctos Linnaeus, 1758 & Brown bear \\
Meles meles (Linnaeus, 1758) & Badger \\
Crocuta crocuta (Erxleben, 1777) & Spotted hyaena \\
Felis silvestris Schreber, 1777 & Wild cat \\
Panthera leo (Linnaeus, 1758) & Lion \\
Palaeoloxodon antiquus (Falconer, 1857) & Straight-tusked elephant \\
Stephanorhinus hemitoechus & Narrow-nosed rhinoceros \\
(Falconer, 1859) & \\
Sus scrofa Linnaeus, 1758 & Wild boar \\
Hippopotamus amphibius Linnaeus, 1758 & Hippopotamus \\
Cervus elaphus Linnaeus, 1758 & Red deer \\
Dama dama (Linnaeus, 1758) & Fallow deer \\
Megaloceros giganteus (Blumenbach, 1799) & Giant deer \\
Bison priscus Bojanus, 1827 & Bison \\
\hline
\end{tabular}

and is here believed to be restricted to Substage $5 \mathrm{e}$ of the marine oxygen isotope record. Uranium series age determinations on stalagmite enclosing hippopotamus bone from Victoria Cave, North Yorkshire have dated the occurrence of this fauna to at or before $120 \pm 6 \mathrm{ka}$ (Gascoyne et al., 1981). Joint Mitnor Cave, Buckfastleigh, Devon, NGR SX 744665, (Sutcliffe, 1960) has been chosen as the defining locality for this widespread faunal assemblage (Currant and Jacobi, 1997) to which we here assign the name Joint Mitnor Cave mammal assemblage-zone (Table 1). At this stage, Britain is believed to have been isolated from continental Europe (Keen, 1995).

The aurochs Bos primigenius Bojanus, 1827, is not known from Joint Mitnor Cave, but has been recorded from other vertebrate assemblages of this age, notably that from Barrington, Cambridgeshire (Gibbard and Stuart, 1975).

Apart from remains of hippopotamus, which are often very abundant at open sites, occurrence of fallow deer, giant deer and, where collected, a small mammal fauna dominated by bank vole, water vole, field vole and wood mouse serves to characterize this assemblagezone. Sutcliffe $(1960,1995)$ has drawn attention to the absence of horse in the "hippopotamus fauna", a feature which also appears to be true of later OIS 5 and OIS 4 mammal assemblages. This is an important and highly consistent absence which distinguishes Late Pleistocene interglacial assemblages from OIS 7 and earlier temperate stage faunas in which horse is well represented.

The upper and lower boundaries of this assemblagezone are quite well defined. At Waterhall Farm near Hertford, a fluviatile sequence with a Joint Mitnor Cave assemblage-zone fauna overlay marls containing a particularly large form of the northern vole Microtus oeconomus. In Minchin Hole and Bacon Hole on the Gower Coast the same large form of northern vole is associated with deposits immediately underlying the Last Interglacial "Patella Beach" of George (1932). In the Coarse Sands at Bacon Hole, the large northern vole occurs together with red fox and a notably small form of horse in association with a terrestrial molluscan assemblage indicating cold, dry conditions (Currant et al., 1984). This limited assemblage has been attributed to OIS 6 (Schreve, 1997). The Patella Beach and its correlatives in Minchin Hole and the Sandy BreccioConglomerate, Sandy Cave Earth and Shelly Sand in the Bacon Hole sequence have yielded faunas entirely consistent with the composition of the Joint Mitnor Cave mammal assemblage-zone, although remains of hippopotamus have not been recovered (Currant et al., 1984; Sutcliffe et al., 1987). One of our reasons for adopting the assemblage-zone concept was to overcome exactly this kind of difficulty. Topographical and taphonomic factors can sometimes influence the 
composition of mammal assemblages, and we believe that this has happened on Gower where the landscape may have limited hippopotamus distribution. Although one of the key elements is missing, the rest of the mammals found in the above group of deposits is sufficient to confirm the assemblage-zone attribution. The Shelly Sand at Bacon Hole is directly overlain by deposits containing fossils characterizing the succeeding Bacon Hole mammal assemblage-zone. Although the mammalian assemblage may not be expressed in what we have come to accept as its most characteristic form, the stratigraphic sequence at Bacon Hole provides us with the best definition of the upper and lower limits of the Joint Mitnor Cave mammal assemblage-zone.

Human artefacts have been claimed to occur at several Late Pleistocene localities at which hippopotamus has also been found. Currant and Jacobi (2001) have re-examined these and found none to be convincing.

\section{The Bacon Hole mammal assemblage-zone}

Later Stage 5 faunas, still thoroughly interglacial in character but lacking hippopotamus are known from a number of sites, notably Bacon Hole on the Gower Peninsula in South Wales. We assign these assemblages to the Bacon Hole mammal assemblage-zone as defined by the fauna from the Grey Clays, Silts and Sands (Unit G) and the overlying Upper Sands (Unit H) and Upper Cave Earth (Unit I) at Bacon Hole, Southgate, West Glamorgan, NGR SS 559868 (Sutcliffe et al., 1987) (Table 2).

On Gower there is clear evidence of a mammalian assemblage with straight-tusked elephant and narrow-nosed rhinoceros surviving for some considerable time after the high sea level event attributed to Substage 5e. Recent TIMS dating by Mabs Gilmour of The Open University of a flowstone floor capping the Bacon Hole Last Interglacial faunas (i.e. on top of the Upper Cave Earth) has produced an age close to $87 \mathrm{ka}$ and with a very small error margin. We consider that faunas with a strongly interglacial character were present in Britain throughout OIS 5 and in this respect we differ from the interpretation put forward for the Cassington sequence set out by Maddy et al. (1998). Evidence for very open environments in the later substages of OIS 5 is here attributed, at least in part, to the sustained environmental impact of megaherbivores.

Fallow deer and giant deer, both common elements of the Joint Mitnor Cave mammal assemblage-zone, are notably absent from this part of the Bacon Hole sequence. Significant additions to the later Stage 5 fauna at Bacon Hole are the northern vole, mammoth (Fig. 1) and roe deer. The arrival of these species may
Table 2

The mammal fauna from the Grey Clays, Silts and Sands, Upper Sands and Upper Cave Earth at Bacon Hole, Southgate, West Glamorgan

\begin{tabular}{|c|c|}
\hline \\
\hline \multicolumn{2}{|l|}{$\begin{array}{l}\text { I Upper Cave Earth / H Upper Sands } \\
\text { Arvicola terrestris cantiana (Hinton, 1910) }\end{array}$} \\
\hline Microtus oeconomus (Pallas, 1776) & Northern vole \\
\hline Canis lupus Linnaeus, 1758 & Wolf \\
\hline Crocuta crocuta (Erxleben, 1777) & Spotted hyaena \\
\hline Palaeoloxodon antiquus (Falconer, 1857) & Straight-tusked elephant \\
\hline $\begin{array}{l}\text { Stephanorhinus hemitoechus } \\
\text { (Falconer, 1859) }\end{array}$ & Narrow-nosed rhinoceros \\
\hline Cervus elaphus (Linnaeus, 1758) & Red deer \\
\hline Bison priscus Bojanus, 1827 & Bison \\
\hline G Grey Clays, Silts and Sands & \\
\hline Sorex araneus Linnaeus, 1758 & Eurasian common shrew \\
\hline Clethrionomys glareolus (Schreber, 1780) & Bank vole \\
\hline Arvicola terrestris cantiana (Hinton, 1910) & Water vole \\
\hline Microtus oeconomus (Pallas, 1776) & Northern vole \\
\hline Microtus agrestis (Linnaeus, 1761) & Field vole \\
\hline Apodemus sylvaticus (Linnaeus, 1758) & Wood mouse \\
\hline Palaeoloxodon antiquus (Falconer, 1857) & Straight-tusked elephant \\
\hline $\begin{array}{l}\text { Mammuthus primigenius } \\
\text { (Blumenbach, 1799) }\end{array}$ & Woolly mammoth \\
\hline $\begin{array}{l}\text { Stephanorhinus hemitoechus } \\
\text { (Falconer, 1859) }\end{array}$ & Narrow-nosed rhinoceros \\
\hline Crocuta crocuta (Erxleben, 1777) & Spotted hyaena \\
\hline Canis lupus Linnaeus, 1756 & Wolf \\
\hline Meles meles (Linnaeus, 1758) & Badger \\
\hline Cervus elaphus Linnaeus, 1758 & Red deer \\
\hline Capreolus capreolus Linnaeus, 1758 & Roe deer \\
\hline Bison priscus Bojanus, 1827 & Bison \\
\hline
\end{tabular}

indicate that Great Britain was not an island throughout all of OIS 5, although the detailed local sea level record is sparse (Keen, 1995). The occurrence of northern vole Microtus oeconomus is one of the key elements which distinguishes the Bacon Hole mammal assemblage-zone from the preceding Joint Mitnor Cave Mammal assemblage-zone, though the exact nature of the transition between these two assemblages remains to be seen.

Occurrences of deposits containing fossils characteristic of the Bacon Hole mammal assemblage-zone appear to be genuinely rare, possibly because they represent a period in which the interglacial landscape was maturing and relatively few opportunities for longterm burial and preservation were available. The Gower coast is unusual in that a series of caves happen to occur at a level roughly coincident with OIS 5 maximum high sea levels. As sea level fell towards the end of the stage these large caves were open and sediments accumulated on top of the substage 5e littoral deposits. By the same process, during the present interglacial, these deeply buried sequences have been re-exposed by marine erosion.

The upper and lower limits of this assemblage-zone are well constrained at the type locality as discussed elsewhere in this paper. 


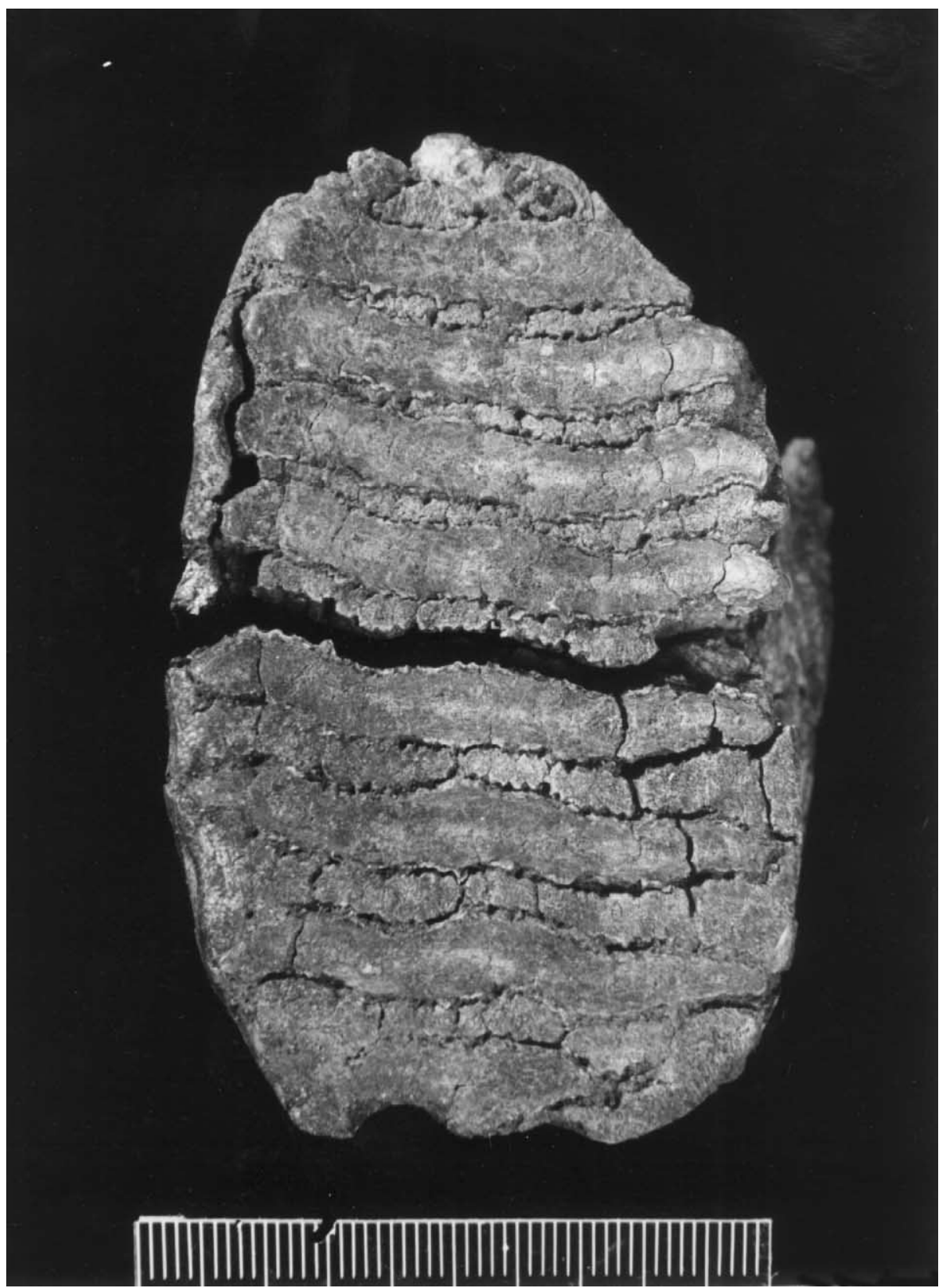

Fig. 1. Occlusal surface of an upper left DP4, Mammuthus primigenius, NHM Palaeont. Dept M33503, from the Grey Clay of Unit G, the Grey Clays, Silts and Sands at Bacon Hole, West Glamorgan (BH75 Area IV \#224). This is the first confirmed record of mammoth from a late OIS 5 context in Britain.

\section{The Banwell Bone Cave mammal assemblage-zone}

We have identified a low species diversity vertebrate fauna of widespread occurrence and remarkably consistent composition which occupies the British region during a period later than the interglacial faunas mentioned above but earlier than assemblages usually attributed to the Middle Devensian (Currant and Jacobi, 1997). Bison and reindeer are the dominant elements of this fauna, with wolf, wolverine, mountain hare and an extremely large variety of brown bear (e.g. Kurten, 1964) as their consistent companions. For much if not all of this period the small mammal fauna is restricted to a single species, the northern vole. This community is very similar to that found in the higher latitudes of North America up to modern times. It is clearly the vertebrate assemblage of a cold environment but it should be noted that it is markedly different in character from the fauna of the succeeding stage. Banwell Bone Cave, Banwell, Somerset, NGR ST 
Table 3

The mammal fauna from Banwell Bone Cave, Banwell, Somerset

\begin{tabular}{ll}
\hline Lepus timidus Linnaeus, 1758 & Mountain hare \\
Microtus oeconomus (Pallas, 1776) & Northern vole \\
Canis lupus (Linnaeus, 1758) & Wolf \\
Vulpes vulpes (Linnaeus, 1758) & Red fox \\
Vulpes lagopus (Linnaeus, 1758) & Arctic fox \\
Ursus arctos Linnaeus, 1758 & Brown bear; a very large form \\
Gulo gulo (Linnaeus, 1758) & Wolverine \\
Rangifer tarandus (Linnaeus, 1758) & Reindeer \\
Bison priscus Bojanus, 1827 & Bison \\
\hline
\end{tabular}

383588 , has been chosen as the defining locality for this assemblage (Rutter, 1829; Currant and Jacobi, 1997; Currant, 1999) to which we assign the name Banwell Bone Cave mammal assemblage-zone (Table 3) .

The record of leopard Panthera pardus (Linnaeus, 1758) from Banwell Bone Cave previously listed (Currant and Jacobi, 1997) is based on a single canine from the Enniskillen Collection, now in the Natural History Museum, London (NHM). This specimen would almost certainly have come from the collection of William Beard, first excavator of the cave. Given that leopard is represented in the fauna from the nearby late Middle Pleistocene site of Bleadon Cavern which was also collected by Beard, we feel that this is the more likely provenance for the NHM specimen. There is only one other confirmed record of leopard from Britain and that is also from deposits of late Middle Pleistocene age at Pontnewydd Cave, Clwyd, North Wales (Currant, 1984).

At Banwell, the sheer volume of bone bearing deposit argues for a long period of relative faunal stability. The Banwell Bone Cave mammal assemblage-zone is here identified at both Cassington and Isleworth. The biota reported from each of these sites suggests interstadial conditions but the beetles and the pollen are sufficiently different for them not to represent the same period of time (Maddy et al., 1998). We see this as a supporting argument for the longevity of this mammal assemblage-zone.

At Tornewton Cave in Devon, deposits containing a Banwell Bone Cave mammal assemblage-zone fauna can be shown to overlie deposits which appear to span the Last Interglacial complex (Currant, 1998). The same relationship may exist at Bacon Hole on Gower where rare fossils of wolverine, brown bear and reindeer have been found in the breccias overlying the deposits characterizing the Bacon Hole mammal assemblagezone and separated from them by a flowstone floor dated to $87 \mathrm{ka}$ (see above). As this is probably one of the commonest but least familiar of our faunal assemblages we list significant occurrences, several of which further confirm its stratigraphic position, in Table 4. The faunal remains from most of the sites in the following list have been re-examined by the authors. We have not seen the material from Cassington or the collections from Tattershall Castle.

At Stump Cross Cave new TIMS dates on flowstone enclosing bones of wolverine are close to $74 \mathrm{ka}$ (Mabs Gilmour, pers. comm.), significantly postdating the flowstone capping the interglacial sequence at Bacon Hole. Previously reported dates on this stalagmite in the order of $83 \mathrm{ka}$ (Sutcliffe et al., 1985) lack the precision of the new results (Gilmour et al., in preparation).

Despite a very thorough review, we find that there are no verifiable records of either artefacts or human fossils found in association with the Banwell Bone Cave mammal assemblage-zone.

\section{The Pin Hole mammal assemblage zone}

Human populations appear to return to Britain in association with a vertebrate fauna including spotted hyaena, mammoth, horse and woolly rhinoceros during OIS 3. A large number of the cave sites representing this faunal grouping are interpreted as spotted hyaena dens. Previously we had proposed Coygan Cave, Laugharne, Dyfed, SN 284091 as the defining locality for our "Coygan-type fauna" (Currant and Jacobi, 1997). Sadly, Coygan Cave was completely destroyed by quarrying some years ago and although investigations at this site have been extensively reviewed by AldhouseGreen et al. (1995) we feel that it is vitally important to have a type locality which is still available for reference and future investigation. Pin Hole, Creswell, Derbyshire, in the Creswell Crags S.S.S.I., NGR SK 533742, has been substituted as the defining locality for this faunal grouping, specifically the material from the Lower Cave Earth at Pin Hole, and this is accordingly named the Pin Hole mammal assemblage-zone (Table 5). Other reasons for preferring this locality are its rich, but as yet unreported, small mammal fauna collected during excavations from 1984 to 1989, birds, fish, amphibians and the preservation of contemporary pollen both within the cave deposits (Coles, 1987) and in spotted hyaena coprolites (Mark Lewis, pers. comm.). The age of the fauna is also particularly well constrained by a combination of Uranium-series, ESR, and radiocarbon dates. These are consistent with accumulation during the interval 50-38 ka (Jacobi et al., 1998).

Red deer Cervus elaphus (Linnaeus, 1758) has not been identified as part of the Pin Hole fauna but is a consistent component of Middle Devensian faunas in Southern Britain where it is usually represented by an extremely large form. Remains of Arctic fox Vulpes lagopus from Pin Hole are unstratified, but this species is recorded from other Middle Devensian localities including Coygan Cave (Aldhouse-Green et al., 1995). There is also a record of wolverine from Pin Hole but its associations are unclear. Small mammals recovered 
Table 4

Sites and stratigraphic units containing a Banwell Bone Cave mammal assemblage-zone fauna

The Arch (also known as "Lion's Mouth"), Creswell, Derbyshire

Ash Tree Cave, Whitwell, Derbyshire; basal clay

Banwell Bone Cave, Banwell, Somerset (Rutter, 1829)

Bleadon Quarry, Bleadon, Somerset (Anon., 1879)

Bosco's Den, Southgate, West Glamorgan (Falconer in Murchison, 1868)

Brean Down, Somerset; beds 12 and 13 (Savage in ApSimon et al., 1961)

Cassington, Oxfordshire; facies associations A and B (Maddy et al., 1998)

Hyaena Den, Wookey Hole, Somerset; water laid sediments (Jacobi and Hawkes, 1993)

Kew Bridge Station, Middlesex (Morris, 1850; Kurten, 1964)

Limekiln Hill Quarry, Mells, Somerset; lower fauna

Pen Park Quarry, Bristol

Picken's Hole, Compton Bishop, Somerset; layer 5 (Tratman, 1964; ApSimon, 1986)

Port Eynon Point Cave, Porteynon, West Glamorgan

Steetley Wood Cave, Steetley, Nottinghamshire

Stump Cross Cave, Pateley Bridge, North Yorkshire (Sutcliffe et al., 1985)

Tattershall Castle, Lincolnshire; upper silt bed (Rackham, 1978)

Tornewton Cave, Devon; sediments in Price's Passage

Twickenham, Middlesex (Leeson and Laffan, 1894)

Willment's Pit, Isleworth, Middlesex; basal silts (Coope and Angus, 1975; Kerney et al., 1982)

Windsor, Berkshire (Dawkins, 1880, pp. 155-156)

Windy Knoll Cave, Castleton, Derbyshire (Dawkins, 1877).

from excavations in nearby Robin Hood Cave (Area A, S.W. corner of Western Chamber) in direct association with a Pin Hole mammal assemblage zone fauna include Dicrostonyx torquatus, Microtus oeconomus, Microtus gregalis and Arvicola terrestris.

Recent fieldwork and associated research at at least six localities confirm Banwell Bone Cave mammal assemblage-zone faunas as being older than those of the Pin Hole mammal assemblage-zone: Ash Tree Cave, the sand cliff at Brean Down, Cassington, the Hyaena Den at Wookey Hole, Limekiln Hill Quarry and Picken's Hole. Nowhere can a Pin Hole mammal assemblage-zone fauna be shown to underlie or be interstratified with a Banwell Bone Cave mammal assemblage-zone fauna.

The Pin Hole Lower Cave Earth fauna is a western extension of the characteristic later Quaternary assemblage of much of central Asia north of the Himalayas. As such, we may assume that its occurrence in Britain indicates the extension of extreme continental conditions right up to the Atlantic seaboard (cf. Coope, 1973; Ullrich and Coope, 1974). Guthrie (1982) uses the term "Mammoth Steppe" to describe the vegetation associated with and to a large extent maintained by this distinctive animal community.

It seems to us that this fauna is most likely to be principally of OIS 3 age and we have found nothing to contradict this interpretation (Jacobi et al., 1998).

With this assemblage-zone we pass into the period in which faunal remains are susceptible to radiocarbon dating. As spotted hyaenas are one of the characteristic components of these faunas we have used radiocarbon dates on this species to gauge the time span of the Pin Hole mammal assemblage-zone. This series of age determinations (Table 6) is on recently collected specimens from caves in the Creswell area.

Although we do not yet have a very precise fix on the earlier end of the timescale, it is likely that the Pin Hole mammal assemblage-zone spans at least 30,000 years. It should be noted that no investigator has so far reported any internal biostratigraphic patterning within deposits containing Pin Hole mammal assemblage-zone faunas in spite of the climatic instability also documented for this period by the Greenland ice core data (e.g. Bond et al., 1993). It is very likely that the faunal material assigned to this assemblage zone represents something of a mixture, reflecting the coarse grain of the recovered fossil record as compared with the increasingly fine grain of the global environmental signal as derived from ice core data and continuous pollen sequences (e.g. Woillard and Mook, 1982).

Humans are represented as part of the fauna of the Pin Hole mammal assemblage-zone by skeletal material at Kent's Cavern and Paviland and by artefacts of Middle and Early Upper Palaeolithic types at more than 30 other localities (Currant and Jacobi, in press).

\section{The Dimlington Stadial interzone}

The upper limit of the Pin Hole mammal assemblagezone as currently envisaged is defined by an interzone corresponding to much of the Dimlington Stadial, the main Late Devensian glacial advance (Rose, 1985) in which mammalian fossils are comparatively rare. Although there are radiocarbon age determinations on various individual fossils which may relate to this period, it is not possible at this stage to select a type 
Table 5

The mammal fauna from the Lower Cave Earth at Pin Hole, Creswell, Derbyshire

\section{Homo sp.}

Lepus timidus Linnaeus, 1758

Spermophilus major Pallas, 1779

Canis lupus (Linnaeus, 1758)

Vulpes vulpes Linnaeus, 1758

Ursus arctos Linnaeus, 1758

Mustela erminea Linnaeus, 1758

Mustela putorius Linnaeus, 1758

Crocuta crocuta (Erxleben,1777)

Panthera leo (Linnaeus, 1758)

Mammuthus primigenius (Blumenbach, 1799)

Equus ferus Boddaert, 1785

Megaloceros giganteus (Blumenbach, 1799)

Rangifer tarandus (Linnaeus, 1758)

Bison priscus Bojanus, 1827
Coelodonta antiquitatis (Blumenbach, 1799)

(Artefacts)
Mountain hare
Red-cheeked suslik
Wolf
Red fox
Brown bear
Stoat
Polecat
Spotted hyaena
Lion
Woolly mammoth
Wild horse
Woolly rhinoceros
Giant deer
Reindeer
Bison

Table 6

Radiocarbon dates on Crocuta crocuta remains from the Creswell area $^{\mathrm{a}}$

\begin{tabular}{llll}
\hline Robin Hood Cave & OxA-6115 & $22,880 \pm 240$ & 1. \\
Robin Hood Cave & OxA-6114 & $22,980 \pm 480$ & 1. \\
Church Hole & OxA-5800 & $24,000 \pm 260$ & 2. \\
Ash Tree Cave & OxA-5798 & $25,660 \pm 380$ & 2. \\
Church Hole & OxA-5799 & $26,840 \pm 420$ & 2. \\
West Pin Hole (Dog Hole) & OxA-5803 & $29,300 \pm 420$ & 2. \\
Robin Hood Cave & OxA-5802 & $31,050 \pm 500$ & 2. \\
Pin Hole & OxA-1206 & $32,200 \pm 1000$ & 3. \\
Robin Hood Cave & OxA-5801 & $33,450 \pm 700$ & 2. \\
Pin Hole & OxA-1207 & $34,500 \pm 1200$ & 3. \\
Pin Hole & OxA-4754 & $37,800 \pm 1600$ & 2. \\
Pin Hole & OxA-1448 & $42,200 \pm 3000$ & 4. \\
\hline
\end{tabular}

${ }^{\text {a }}$ References: 1. Hedges et al., 1998; 2. Hedges et al., 1996; 3. Hedges et al., 1988; 4. Hedges et al., 1989.

locality or define a characteristic vertebrate assemblage which would have biostratigraphic integrity. The interzone name given above is given no formal status in the model presented here but we believe that the concept is useful.

\section{The Gough's Cave mammal assemblage-zone}

The Late Glacial period in Britain is generally characterized by mammal faunas in which horse and reindeer are relatively common, but it is clear from radiocarbon age determinations from around the country that there is quite marked regional patterning in the distribution of particular species (Housley, 1991). Finds representing such species as the elk Alces alces and mammoth (other than in the form of human artefacts) have a northern distribution, while the most northerly British record of pika Ochotona pusilla is from Robin Hood Cave at Creswell in the East Midlands. Red deer
Cervus elaphus certainly seems to be much better represented in the southwest of Britain, at times to the exclusion of reindeer. Against this background of regionality we have tried to identify faunal groupings within the Late Glacial which have a more than local biostratigraphic utility and which also have viable type localities. In spite of changes in the relative abundance of individual species and changing patterns of presence and absence of some of the rarer elements of the fauna, we can only identify one overall mammalian assemblage. The fauna from the cave earth and breccia unit at Gough's Cave, Cheddar, Somerset, NGR ST 467539, can be taken as broadly representative of the whole of the Late Glacial or Windermere Interstadial and much, if not all, of the Loch Lomond Stadial and terminal Pleistocene. We assign the name Gough's Cave mammal assemblage-zone to deposits containing this faunal grouping (Table 7).

Records of pika Ochotona pusilla, beaver Castor fiber and water vole Arvicola terrestris from this unit at Gough's Cave have not been confirmed in recent excavations or by direct dating of fossils in existing collections. For present purposes they are omitted from the faunal list given above, but these species are certainly present within the Late Glacial mammal fauna. The stratigraphic position of this assemblage-zone is inferred from a major series of radiocarbon age determinations on material collected from Gough's Cave (Currant, 1991). These determinations give an age range for the Gough's Cave mammal assemblagezone at the type locality in the order of $12,900-9900$ radiocarbon years (Housley, 1991). In the earlier part of the Gough's Cave cave earth and breccia sequence red deer is the dominant local cervid with reindeer only being represented in the form of human artefacts, but higher in the unit reindeer is represented by teeth and unworked skeletal elements. We have found no evidence of bison, spotted hyaena or woolly rhinoceros in deposits attributable to this assemblage-zone and these notable absences help establish a distinction between the Gough's Cave and Pin Hole mammal assemblage-zones.

Much of the Gough's Cave material is fairly clearly a human predation assemblage and many of the recorded findings show evidence of deliberate butchery and breakage. The record of mammoth is based solely on artefacts which may have been transported to the cave, but there are contemporary radiocarbon dates for this species from elsewhere in Britain (Housley, 1991; Lister, 1991). Such occurrences are an important extension of the potential utility of this biostratigraphic unit. Human artefacts from Gough's Cave are Upper Palaeolithic and principally Creswellian (Jacobi, 1991). Elements of this faunal grouping have also been found in association with Creswellian artefacts at Soldier's Hole (Parry, 1931), Aveline's Hole (Davies, 1921), King Arthur's Cave (Taylor, 1928), Kent's Cavern and Three Holes 
Table 7

Late Glacial Interstadial mammals from the cave earth and breccia unit in the entrance to Gough's Cave, Cheddar

AMS dated

Homo sapiens Linnaeus, 1758

Lepus timidus (Linnaeus, 1758)

Dicrostonyx torquatus Pallas, 1779

Lemmus lemmus (Linnaeus, 1758)

Microtus oeconomus (Pallas, 1776)

Microtus gregalis (Pallas, 1779)

Canis lupus Linnaeus, 1758

Vulpes vulpes (Linnaeus, 1758)

Vulpes lagopus (Linnaeus 1758)

Ursus arctos Linnaeus, 1758

Lynx lynx (Linnaeus, 1758)

Mammuthus primigenius (Blumenbach, 1799)

Equus ferus Boddaert, 1785

Cervus elaphus Linnaeus, 1758

Rangifer tarandus (Linnaeus, 1758)

Bos primigenius Bojanus, 1827

Saiga tatarica (Linnaeus, 1766)
Human

Mountain hare

Collared lemming

Norway lemming

Northern vole

Narrow-skulled vole

Wolf

Red fox

Arctic fox

Brown bear

Lynx

Mammoth (human artefacts)

Wild horse

Red deer

Reindeer

Aurochs

Saiga antelope
$+$

$+$
Cave (Hedges et al., 1996) and in each case the age has been confirmed by radiocarbon dating.

The lower boundary of the Gough's Cave mammal assemblage-zone is poorly constrained. At Gough's Cave the cave earth and breccia unit lies unconformably on an unfossiliferous waterlain conglomerate of unknown age. Individual components of this fauna have been found at King Arthur's Cave, Wye Valley, in the "Second Hearth" lying directly above deposits containing a Pin Hole mammal assemblage-zone fauna (Taylor, 1928; ApSimon et al., 1992). At sites such as Kent's Cavern and Soldier's Hole elements of the Gough's Cave fauna are recorded as from the topmost part of deposits which otherwise contain a Pin Hole mammal assemblage-zone fauna. In each case radiocarbon dating indicates a considerable lapse of time between the faunal groupings.

The upper limit of the Gough's Cave mammal assemblage zone can currently only be inferred. The most recent excavations at Gough's Cave were confined to the lower part of the cave earth and breccia unit. Remains of reindeer mentioned above, which have yielded age determinations in the range 10,500-9900 radiocarbon years, rather later than the rest of the assemblage (Currant, 1991). In the now destroyed sequence reported from Chelm's Combe, Cheddar the local faunal record appears to have continued from the red deer to reindeer transition suggested at Gough's Cave up to the end of the Pleistocene and into the Holocene (Jackson, Palmer et al., 1927), but no surviving parallel to this important site has yet been identified.

Recent work by Coard and Chamberlain (1999) has also begun to resolve some of the faunal changes taking place across the Pleistocene to Holocene boundary, but their argument is dependent on radiocarbon age determinations on individual faunal elements taken from a number of sites. It is perhaps inevitable that the level of discrimination being sought to determine the finer detail of the faunal response to a period of rapid environmental change requires a different kind of analysis to that which is appropriate to the coarser grained fossil record of earlier periods.

\section{Concluding remarks}

It is one of the principles of biostratigraphy that absence of evidence is not necessarily evidence of absence (Lister, 1992, p. 330). In preparing this paper, we have kept this point firmly in mind.

Here, we have outlined a simple biostratigraphic framework for the British Late Pleistocene against which the factors governing human presence and absence can be assessed and the details of faunal history recorded. It appears to us that human activity in Britain during the Late Pleistocene is restricted to the Middle and Late Devensian, particularly the Lateglacial Interstadial (Jacobi, 1991). It should be emphasised that this is a practical biostratigraphy based on the physical attributes of the fossil record as it is currently known. The area of its direct application is intended to be the island of Great Britain but for all practical purposes the evidence on which our model is based is restricted to England and Wales. However, although it is beyond the scope of the present paper, we would expect the biozonation outlined here to be broadly applicable to adjacent parts of NW Europe and possibly ever further afield but this will need to be tested by those with detailed knowledge of local sequences and collections. Island insularity during the early part of OIS 5 may account for the apparent uniqueness of the Joint Mitnor Cave mammal assemblage-zone, but there is good evidence for a greater or lesser degree of land 
connection between Britain and the rest of Europe during much of the rest of the Late Pleistocene.

\section{Acknowledgements}

We would like to thank all of those individuals and institutions who so readily made their material available for us to study and our referees for making a number of constructive comments which have improved the clarity of the final text.

\section{References}

Aldhouse-Green, S., Scott, K., Schwarcz, H., Grün, R., Housley, R., Rae, A., Bevins, R., Redknap, M., 1995. Coygan Cave, Laugharne, South Wales, a Mousterian site and hyaena den: a report on the University of Cambridge excavation. Proceedings of the Prehistoric Society $61,37-79$.

Anon. 1879. The Museum. Additions since the publication of the last volume. Proceedings of the Somersetshire Archaeological and Natural History Society 24, 70-72.

ApSimon, A.M., 1986. Pickens Hole, Compton Bishop, Somerset: early Devensian bear and wolf den, and Middle Devensian hyaena den and Palaeolithic site. In: Collcutt, S.N. (Ed.), The Palaeolithic of Britain and its Nearest Neighbours: Recent Trends. Department of Archaeology and Prehistory, University of Sheffield, Sheffield, pp. 55-56.

ApSimon, A.M., Smart, P.L., Macphail, R., Scott, K., Taylor, H., 1992. King Arthurs Cave, Whitchurch, Herefordshire: reassessment of a Middle and Upper Palaeolithic, Mesolithic and beaker site. Proceedings of the University of Bristol Spelaeological Society 19, 183-249.

Bond, G., Broecker, W., Johnsen, S., McManus, J., Labeyrie, L., Jouzel, J., Bonani, G., 1993. Correlations between climate records from North Atlantic sediments and Greenland ice. Nature 365, 143-147.

Coard, R., Chamberlain, A.T., 1999. The Nature and timing of faunal change in the British Isles across the Pleistocene/Holocene transition. The Holocene 9, 372-376.

Coles, G., 1987, Aspects of the Application of Palynology to Cave Deposits in the magnesian Limestone Region of North Nottinghamshire. Unpublished $\mathrm{Ph}$. D. Thesis, University of Sheffield.

Coope, G.R., 1973. Tibetan Species of Dung Beetle from Late Pleistocene Deposits in England. Nature 245, 335-336.

Coope, G.R., Angus, 1975. An ecological study of a temperate interlude in the middle of the last glaciation, based on fossil Coleoptera from Isleworth, Middlesex. Journal of Animal Ecology 44, 365-391.

Currant, A.P., 1984. The mammalian remains. In: H.S. Green (Ed.), Pontnewydd Cave, A Lower Palaeolithic hominid site in Wales, National Museum of Wales, Cardiff, pp. 171-180.

Currant, A.P., 1991. A Late Glacial Interstadial mammal fauna from Goughs Cave, Somerset, England. In: Barton, N., Roberts, A.J., Roe, D.A. (Eds.), The Late Glacial in North-West Europe: Human Adaptation and Environmental Change at the End of the Pleistocene. Council for British Archaeology, London, pp. 48-50.

Currant, A.P., 1998. Tornewton Cave. In: Campbell, S., Hunt, C.O., Scourse, J.D., Keen, D.H. (Eds.), Quaternary of South-West England. Chapman \& Hall, London, pp. 138-145.

Currant, A., 1999. Note on the Banwell Bone Cave and its Pleistocene Fauna. Axbridge Archaeological and Local History Society Journal, 10-12.
Currant, A., Jacobi, R., 1997. Vertebrate faunas of the British Late Pleistocene and the chronology of human settlement. Quaternary Newsletter 82, 1-8.

Currant, A., Jacobi, R., 2001. Human presence and absence in Britain during the early part of the Late Pleistocene. Paper submitted for an yet unnamed Amiens conference volume, in press.

Currant, A.P., Stringer, C.B., Collcutt, S.N., 1984. Bacon Hole Cave. In: Bowen, D.Q., Henry, A. (Eds.), Wales: Gower, Preseli, Fforest Fawr Field Guide. Quaternary Research Association, Cambridge, pp. $38-45$.

Davies, J.A., 1921. Avelines Hole, Burrington Coombe: an Upper Palaeolithic station. Proceedings of the University of Bristol Spelaeological Society 2, 61-72.

Dawkins, W.B., 1877. The exploration of the ossiferous deposit at Windy Knoll, Castleton, Derbyshire, by Rooke Pennington, Esq., LL. B., F.G.S, and Prof. Boyd Dawkins, M.A., F.R.S. Quarterly Journal of the Geological Society of London 33, 724-729.

Dawkins, W. B., 1880. Early Man in Britain. Macmillan and Co., London.

Falconer, H., 1868. In: Murchison, C. (Ed.), Palaeontological Memoirs and Notes of the Late Huge Falconer, A.M., M.D, Vol. 2. Robert Hardwicke, London.

Gascoyne, M., Currant, A.P., Lord, T.C., 1981. Ipswichian fauna of Victoria Cave and the marine palaeoclimatic record. Nature 294, 652-654.

George, T.N., 1932. The Quaternary Beaches of Gower. Proceedings of the Geologists Association 43, 291-324.

Gibbard, P.L., Stuart, A.J., 1975. Flora and vertebrate fauna of the Barrington Beds. Geological Magazine 112, 493-501.

Guthrie, R.D., 1982. Mammals of the mammoth steppe as palaeoenvironmental indicators. In: Hopkins, J.V., Matthews, C.E., Schweger C, .E., Young, S.B. (Eds.), Palaeoecology of Beringia. Academic Press, London, pp. 307-326.

Hedges, R.E.M., Housley, R.A., Law, I.A., Bronk, C.R., 1989. Radiocarbon dates from the Oxford AMS system: Archaeometry datelist 9. Archaeometry 31, 207-234.

Hedges, R.E.M., Housley, R.A., Law I, .A., Perry, C., 1988. Radiocarbon dates from the Oxford AMS system: Archaeometry datelist 7. Archaeometry 30, 155-164.

Hedges, R.E.M., Pettitt, P.B., Bronk Ramsey, C., van Klinken, G.J., 1996. Radiocarbon dates from the Oxford AMS system: Archaeometry datelist 22. Archaeometry 38, 391-415.

Hedges, R.E.M., Pettitt, P.B., Bronk Ramsey, C., van Klinken, G.J., 1998. Radiocarbon dates from the Oxford AMS system: Archaeometry datelist 26. Archaeometry 40, 437-455.

Housley, R.A., 1991. AMS dates from the Late Glacial and early Postglacial in north-west Europe: a review. In: Barton, N., Roberts, A.J., Roe, D.A. (Eds.), The Late Glacial in north-west Europe: human adaptation and environmental change at the end of the Pleistocene. Council for British Archaeology, London, pp. 25-39.

Jackson, J.W., 1927. The vertebrate and molluscan fauna. In: Palmer, T.F., Balch, H.E., Cooper, N.C., Clay, R.C.C., Jackson, J.W. (Eds.), Excavations at Chelm's Combe, Cheddar. Proceedings of the Somersetshire Archaeological and Natural History Society 72, 93-124.

Jacobi, R., 1991. The Creswellian, Creswell and Cheddar. In: Barton, N., Roberts, A.J., Roe, D.A. (Eds.), The Late Glacial in north-west Europe: human adaptation and environmental change at the end of the Pleistocene. London, Council for British Archaeology, pp. $128-140$.

Jacobi, R.M., Hawkes, C.J., 1993. Archaeological notes: work at the Hyaena Den, Wookey Hole. Proceedings of the University of Bristol Spelaeological Society 19, 369-371.

Jacobi, R.M., Rowe, P.J., Gilmour, M.A., Grün, R., Atkinson, T.C., 1998. Radiometric dating of the Middle Palaeolithic tool industry 
and associated fauna of Pin Hole Cave, Creswell Crags, England. Journal of Quaternary Science 13, 29-42.

Keen, D.H., 1995. Raised beaches and sea-levels in the English Channel in the Middle and Late Pleistocene: problems of interpretation and implications for the isolation of the British Isles. In: Preece, R.C. (Ed.), Island Britain: a Quaternary Perspective. Geological Society Special Publication 96, London, pp. 63-74.

Kerney, M.P., Gibbard, P.L., Hall, A.R., Robinson, J.E., 1982. Middle Devensian river deposits beneath Upper Floodplain terrace of the River Thames at Isleworth, West London. Proceedings of the Geologists Association 93, 385-393.

King, W.B.R., 1955. The Pleistocene epoch in England. Quarterly Journal of the Geological Society of London 111, 187-208.

Kurten, B., 1964. The evolution of the polar bear, Ursus maritimus Phipps. Acta Zoologica Fennica 108, 1-26.

Leeson, J.R., Laffan, G.B., 1894. On the geology of the Pleistocene deposits in the Valley of the Thames at Twickenham, with contributions to the fauna and flora of the period. Quarterly Journal of the Geological Society of London 50, 453-462.

Lister, A.M., 1992. Mammalian fossils and Quaternary biostratigraphy. Quaternary Science Reviews 11, 329-344.

Lister, A.M., 1991. Late Glacial mammoths in Britain. In: Barton, N., Roberts, A.J., Roe, D.A. (Eds.), The Late Glacial in north-west Europe: human adaptation and environmental change at the end of the Pleistocene. Council for British Archaeology, London, pp. 51-59.

Maddy, D., Lewis, S.G., Scaife, R.G., Bowen, D.Q., Coope, G.R., Green, C.P., Hardaker, T., Keen, D.H., Rees-Jones, J., Parfitt, S., Scott, K., 1998. The Upper Pleistocene deposits at Cassington, near Oxford, England. Journal of Quaternary Science 13, 205-231.

Morris, J., 1850. On the occurrence of mammalian remains at Brentford. Quarterly Journal of the Geological Society of London 6, 201-204.

Parry, R.F., 1931. Excavations at Cheddar. Proceedings of the Somersetshire Archaeological and Natural History Society 76, 46-62.

Rackham, D.J., 1978. Evidence for changing vertebrate communities in the Middle Devensian. Quaternary Newsletter 25, 1-3.

Rose, J., 1985. The Dimlington Stadial/Dimlington Chronozone: a proposal for naming the main glacial episode of the Late Devensian in Britain. Boreas 14, 225-230.
Rutter, J., 1829. Delineations of the north western division of the County of Somerset, and of its antediluvian bone caverns, with a geological sketch of the district. Longman, Rees \& Co., London.

Savage, R.J.G., 1961. The stratigraphy and archaeology of the Late-Glacial and Post-Glacial deposits at Brean Down, Somerset. In: Ap Simon, A.M., Donovan, D.T., Taylor, H. (Eds.), Proceedings of the University of Bristol Spelaeological Society, Vol. 9, pp. $67-136$.

Schreve, D.C., 1997. Mammalian Biostratigraphy of the Later Middle Pleistocene. Unpublished Ph. D. Thesis, University College London.

Sutcliffe, A.J., 1959. The Hippopotamus in Britain. Bulletin of the Mammal Society of the British Isles 11, 36-40.

Sutcliffe, A.J., 1960. Joint Mitnor Cave, Buckfastleigh. Transactions and Proceedings of the Torquay Natural History and Scientific Society $13,1-26$.

Sutcliffe, A.J., 1995. Insularity of the British Isles 250,000-30,000 years ago: the mammalian, including human, evidence. In: Preece, R.C. (Ed.), Island Britain: a Quaternary Perspective. Geological Society Special Publication 96, London, 127-140.

Sutcliffe, A.J., Currant, A.P., Stringer, C.B., 1987. Evidence of sealevel change from coastal caves with raised beach deposits, terrestrial faunas and dated stalagmites. Progress in Oceanography $18,243-271$.

Sutcliffe, A.J., Lord, T.C., Harmon, R.S., Ivanovich, M., Rae, A., Hess, J.W., 1985. Wolverine in northern England at about 83,000 yr B.P.: faunal evidence for climatic change during Isotope Stage 5. Quaternary Research 24, 73-86.

Taylor, H., 1928. King Arthurs Cave, near Whitchurch, Ross-n-Wye. Second Report: Excavations in 1926 and 1927. Proceedings of the University of Bristol Spelaeological Society 3, 59-83.

Tratman, E.K., 1964. Pickens Hole, Crook Peak, Somerset. A Pleistocene site, preliminary note. Proceedings of the University of Bristol Spelaeological Society 10, 112-115.

Ullrich, W.G., Coope, G.R., 1974. Occurrence of the east palaearctic beetle Tachinus jacuticus Poppius (Col. Staphylinidae) in deposits of the Last glacial period in England. Journal of Entomology 42, 207-212.

Woillard, G.M., Mook, W.G., 1982. Carbon-14 dates at Grande Pile: correlation of land and sea chronologies. Science 215, 159-161. 